\title{
Globalizing European Union Environmental Policy
}

\author{
R. Daniel Kelemen \\ Rutgers University \\ dkelemen@polisci.rutgers.edu
}

Paper presented at

The European Union Studies Assocation, $11^{\text {th }}$ Biennial International Conference, Marina Del Rey, California, April 23 ${ }^{\text {rd }}-25^{\text {th }}, 2009$. 


\begin{abstract}
This article explores the EU’s efforts to 'globalize’ EU environmental regulation. EU leadership on global environmental governance emerged as the result of the combined effects of domestic politics and international regulatory competition. The growing power of environmental interests in Europe from the late 1980s, coupled with dynamics of EU policy-making led the EU to be committed to ambitious environmental policies. Given this commitment, it was in the international competitive interests of the EU to support international agreements that would pressure other jurisdictions to adopt similar environmental regulations. Promoting treaties that spread EU environmental norms internationally also served to legitimize EU rules and to shield them against legal challenges before world trade bodies.
\end{abstract}

Keywords: European Union, Environmental Policy, Globalization, WTO 
During the past two decades the European Union (EU) has emerged as the global leader in international environmental politics. On issues ranging from climate change, to biodiversity, to trade in toxic wastes, to the regulation of persistent organic pollutants, the EU has taken on a leadership role in promoting multilateral environmental agreements (MEAs). The EU has also led efforts to 'green' international trade institutions, such as the World Trade Organization (WTO).

Neither the EU itself nor its member states have always been leaders on international environmental policy. When environmental issues emerged on the international scene in the early 1970s, the US took on a leadership role in preparations for the 1972 United Nations (UN) Conference on the Human Environment and championed treaties such as the 1973 Convention on International Trade in Endangered Species (CITES). The US demonstrated leadership again in the mid1980s, acting as the driving force behind the 1987 Montreal Protocol on Ozone Depleting Substances. The precursor to the EU, the European Economic Community (EEC), was not a significant actor in international environmental policy at the time. The member states of the EEC eventually went along with the international treaties created in this period, but in a number of cases, such as the 1979 Convention on Transboundary Air Pollution and the Montreal Protocol, many did so only reluctantly. In the last two decades, however, the EU has emerged as the undisputed leader in international environmental politics. EU leadership is not simply the result of laggard behaviour by the US or other states. Certainly, the US shift from global environmental leader in the 1970s and 1980s to laggard and obstructionist in the 1990s and 2000s opened an opportunity for the EU to assert leadership (Kelemen and 
Vogel, forthcoming; Sbragia and Damro 1999), but the retreat of the US did not force the EU to take on the active leadership role that it has.

This article examines why the EU has taken on this leadership role in international environmental politics. EU leadership in international environmental politics is best explained by a model of 'regulatory politics' (Kelemen and Vogel forthcoming, Raustiala 1997, Desombre 2000) that combines the effects of domestic politics and international regulatory competition. Domestic ${ }^{1}$ political forces have led EU member states and the EU itself to be committed to stringent environmental policies. Given the EU's commitment to high standards and the exposure of European firms to international competition, it is in the competitive interests of the EU to support international agreements that will pressure other states to adopt similarly costly regulations. Moreover, the passage of international environmental agreements can legitimize existing EU rules and thus shield the EU against legal challenges before world trade bodies.

EU leadership in international environmental politics provides striking examples of two of the strategies that Jacoby and Meunier (this volume) highlight as central to the EU's efforts to manage globalization: exercising regulatory influence and empowering international institutions. Globalization generates, or at least is commonly perceived as generating, two primary threats to environmental policy in Europe. First, trade liberalization, it is argued, will pressure EU member states to 'race-to-the-bottom', lowering their standards toward the lowest common denominator in order to maintain competitiveness. The second perceived threat stems from the international institutions charged with promoting economic liberalization, above all the WTO. The logic here is that where EU member states resist race-to-thebottom pressures and maintain stringent environmental standards, these may be struck 
down by the WTO as illegal non-tariff barriers to trade. Whether these threats are real or imagined, they have triggered a reaction from European policy-makers. Policymakers have not treated these globalization pressures as inexorable forces that will determine their policies. Rather, they have sought to manage globalization by spreading EU environmental standards around the world, through support of MEAs and through the EU's normative and market power.

The remainder of the paper is divided into three sections. The first details my ‘regulatory politics' explanation for EU environmental leadership and discusses alternative explanations. The second provides empirical support for the regulatory politics explanation, offering a brief account of the domestic political developments that have led to strong demand for strict environmental policies and show how these demands, coupled with concerns over regulatory competition, stimulated EU leadership on genetically modified organisms (GMOs), climate change and the 'greening' of the world trade regime. The third section concludes.

\section{Explaining EU global environmental leadership}

Some environmental issues, such as climate change, are inherently global and addressing them will require international cooperation. Therefore, any state committed to solving these issues will be inclined to support cooperative, international efforts designed to address them. However, we can not explain the intensity and the scope of the EU's global environmental leadership solely on functional grounds. Global problems may require cooperative solutions, but this does not tell us why the EU has been the chief demandeur of every major international environmental agreement since the early 1990s. Nor can functional considerations 
alone explain EU efforts to 'green' international trade rules and to spread some of its regulatory practices - such as the 'precautionary principle'.

Moving beyond purely functionalist explanations, there is an established literature in political science and sociology examining sources of state support for MEAs. However, the leading arguments in this literature do not offer adequate explanations for the emergence of EU leadership. One line of argument suggests that increases in wealth encourage the spread of post-materialist values that inspire greater public support for environmental protection. As this support is channelled through the political process, it translates into a greater propensity of states to sign and ratify international environmental treaties. A variety of large- $\mathrm{N}$ studies do demonstrate positive correlations between wealth and post-materialist values and the ratification of MEAs (Roberts et al. 2004, Recchia 2002, Scruggs 2003: 83-106). However, arguments based on these factors are designed to predict a state's propensity to sign environmental treaties, not their willingness to play a leadership role. If one stretches these explanations in an effort to explain leadership, they would seem to suggest that the US - not the EU - should have remained the environmental leader in the 1990s. Trends in economic growth and post-materialist values in the 1980s and 1990s when the US made greater gains in both areas than the EU - would not lead one to expect that the EU would assume the mantle of global environmental leadership in the 1990s (Scruggs 2003:106; Kelemen and Vogel, forthcoming).

Scholars working in the social constructivist tradition have argued that a state's support for international environmental treaties is not determined by domestic interests, but rather is ‘constructed' by a ‘world environmental regime’ (Meyer, et al.: 1997) that informs and structures national preferences. States internalize a form of peer pressure, and seek to 'enact' behaviors expected of modern states, including the 
ratification environmental treaties (Frank 1999: 527-529). These scholars argue that the states most deeply embedded in world society tend to ratify more environmental treaties (Frank 1999:534). Whatever the merits of this perspective, it cannot by itself explain EU leadership, because a host of other advanced industrialized democracies such as Japan, the US, Australia and Canada are embedded in world society to a similar degree as the EU, but none of them has asserted a role of global environmental leader on par with the EU.

The literature on EU foreign policy offers a more plausible set of arguments. This literature suggests that the EU has asserted leadership on questions of global environmental governance in an effort to carve out an identity and a profile for itself as a 'normative' or 'civilian' power on the world stage. Since the 1970s, scholars have argued that in light of the EU's limited military capacity and the intractable divisions between member states on security issues, the EU has focused on asserting itself as a 'civilian power' in areas such as trade and human rights where it did have some capacity to act (Duchêne 1972, Zielonka 1998, Hettne and Söderbaum 2005). Similarly, Manners (2002) has argued that the EU is distinguishing itself as a 'normative power' on the international stage, in that it acts to diffuse a series of norms around the world, such as democracy, human rights, and sustainable development. Others have specifically applied this perspective to explain EU leadership on global environmental governance (Scheipers and Sicurelli 2007; Vogler and Stephan 2007).

It is clear that the EU has tried to develop a profile as a civilian or normative power on the world stage, promoting multilateral measures designed to safeguard a variety of norms - including environmental norms (Farrell 2007; Hettne and Söderbaum 2005; Vogler and Stephan 2007). Between the 1970s and 1990s, a series of Treaty amendments, directives and ECJ decisions gave the EU the power to act on 
behalf of its member states in international environmental negotiations, making it possible for the EU to play global leadership role. The EU quickly put this power to use staking out a leadership role at the 1992 Rio Summit, and since then the EU has consistently championed MEAs (Vogler and Stephan 2007, p. 394-396). In 2000 Commission President Romano Prodi summarized these ambitions, explaining, "We must aim to become a global civil power at the service of sustainable global development” (Prodi 2000, p. 3).

This literature suggests a variety of reasons why the EU has made such a priority of spreading its environmental norms. Manners argues that the EU's promotes norms such as sustainable development in order to legitimate itself with sceptical EU citizens (2002, p.244). Scheipers and Sicurelli (2007) suggest that the EU has focused on environmental issues such as climate change in order to develop its identity in contrast to 'the other' of the US. Vogler and Stephan (2007) suggest that the EU's general commitment to multilateralism has been central in explaining its consistent support for MEAs. While the precise causal arguments vary, it does seem likely that the EU's desire to establish an identity and a reputation as a 'normative power’ encouraged EU leadership on global environmental issues.

However, these arguments are notably silent on the question of whether, and if so how, global environmental leadership may have served the material interests of the EU. Were these normative commitments necessary or sufficient conditions for the emergence of EU leadership? Would normative commitments alone have led the EU to take on a leadership role if doing so would have damaged the economic interests of the EU? By contrast, is it possible that economic interests provided the primary motivation for the EU taking on a leadership role, while normative commitments played a secondary, complementary role? 
This article offers a political-economy based explanation for the emergence of EU leadership in international environmental politics. While acknowledging that normative commitments and the desire to develop a reputation as a civilian power played an important complementary role, I argue that the interaction of developments in domestic politics and international regulatory competition provides a more powerful explanation for the emergence of EU environmental leadership.

The regulatory politics perspective (Kelemen and Vogel, forthcoming) fuses domestic politics with international regulatory competition. The ultimate source of a polity's position on international environmental issues can be traced to the strength of environmental constituencies within the political system. The stronger the domestic political influence of environmentalists, the more stringent domestic standards are likely to be and the stronger the political commitment to maintaining those standards in the face of globalization pressures is likely to be. The existence of these strict and entrenched domestic standards in turn makes it more likely that domestic producers will support international treaties that impose similar standards on foreign competitors. Where industry sees that, due to the influence of environmental interests, it will be forced to bear the costs of strict environmental regulations, then it will support (or at least not oppose) efforts to spread those standards to other jurisdictions - sometimes joining them in 'Baptist-Bootlegger coalitions' (Vogel 1995, Desombre 2000, Young 2003). As we will see in the next section, this perspective fits well with the empirical record in the EU, explaining both the general shift toward a leadership position from the early 1990s and the specific positions taken by the EU on a number of important international environmental issues. Instead of allowing globalization pressures to dictate the terms of its environmental policy, the EU has deployed strategies designed to spread its standards to other jurisdictions. 


\section{The political economy of EU global environmental leadership}

The roots of the EU's transformation into the global leader in international environmental politics can be traced to major shifts in domestic environmental politics in Europe beginning in the 1980s. Mass environmental movements had emerged across western Europe in the 1970s, and governments had responded by establishing new pollution control laws. However, environmentalists in Europe never achieved the prominence or power of their US counterparts, and national environmental laws adopted in Europe in this period were generally less stringent than those established in the US (Vogel 2003). The salience of environmental issues - and the political influence of pro-environment forces - declined in the late 1970s in the wake of the oil shocks. However, in the 1980s, a series of highly publicized environmental calamities, including the ‘forest death’ (Waldsterben) caused by acid rain in the early 1980s, the 1986 Chernobyl nuclear disaster and the discovery of the 'hole' in the Ozone layer in the mid-1980s, all heightened the political salience of environmental issues across Europe. These issues, along with scandals concerning cross-border toxic waste shipments in Europe (Kelemen 2004, p. 32), also underlined the increasingly transboundary implications of environmental issues. By the late 1980s, Eurobarometer surveys found environment problems to be one of the chief political concerns in all member states (Hofrichter and Reif 1990). Governments in a number of Member States responded to this public concern by supporting strict new domestic standards and enhanced their commitments to international environmental cooperation.

The sensitivity of national governments to these shifts in public opinion was heightened by the emergence of Green parties. Given the opportunities for the 
emergence of small parties provided by most European electoral systems (particularly those that use proportional representation), environmental activists in Europe became involved in electoral politics in the 1980s. First in Germany in 1983, and later in a number of countries including Sweden, France and Belgium, significant Green parties raised the profile of environmental issues in national political debates (Mair 2001). By the end of the 1990s, Green parties were represented in eleven of fifteen national parliaments in the EU and in the European Parliament (EP) (Vogel 2003). These parties moved increasingly from the fringe to the mainstream of party politics during the 1990s and entered national coalition governments along with social democrats in some member states, most prominently Germany.

The power of environmentalists at the national level was magnified by the dynamics of environmental policy-making at the EU level. First, the European Commission and the European Parliament had strong incentives to see the EU take on a powerful role in environmental policy and to adopt strict standards. National environmental regulations adopted in the 1970s and 1980s threatened to create 'nontariff barriers' that would impede trade and undermine the progress the EU had made toward completing the internal market. With many on the political left arguing at the time that the EU merely served the interests of international business, attacking national environmental standards as non-tariff barriers would have been politically disastrous for the EU. Instead, the EU sought to protect the single market by harmonizing environmental standards at high levels of protection. This approach appealed to the European Commission and the EP because they saw that championing a strong environmental policy would increase the EU's popularity and legitimacy in the eyes of European citizens, demonstrating that the EU did not simply serve business interests but public interests as well. In particular, the EP, whose policy- 
making power was extended dramatically in the late 1990s strengthened, became a champion environmental protection (Pollack 1997). The Commission and Parliament found strong supporters among the greenest member states (the Netherlands, Denmark and, above all, Germany), who viewed the EU as a forum through which they could export their strict standards to laggard Member States (Kelemen 2004; Vogel 2003). ECJ jurisprudence from 1991 onward and Treaty revisions made at Maastricht shifted the decision-making rule for environmental measures from unanimity to qualified majority voting, helping the powerful green states to overcome opposition from laggards (Kelemen 2004, pp.28-31). After the accession of Sweden, Austria and Finland in 1995, the bloc of pro-environment states grew even stronger. Finally, the fact that environment ministers representing their states in the EU's Council of Ministers deliberate amongst themselves - insulated from the critical eyes of ministers of economics and industry - has emboldened them to agree on more ambitious policies (Sbragia 2000).

The combination of the domestic political power of environmentalists and the dynamics of EU policy-making explains why the EU and its member states pursued increasingly stringent and ambitious environmental policies in the 1990s. The policy victories won by environmentalists in Europe unleashed a regulatory competition dynamic. Faced with stringent environmental standards within the EU, European firms and member state governments had strong incentives to see EU standards spread internationally, so that foreign competitors would have to meet similar regulatory burdens. Meanwhile, the EU's capacity to act in a coherent fashion to spread its standards internationally was increasing. This capacity developed gradually, through the extension of the EU's environmental competence and its role in external policies, and through the increasing recognition afforded to the EU in international fora (Jupille 
and Caporaso 1998; Sbragia and Hildebrand 2000:217-18). ${ }^{2}$ These developments culminated in the run-up to the 1992 UN Conference on Environment and Development in Rio where the EU was allowed to join as an equal participant and Commission President Jacques Delors was given a status equivalent to head of state (Vogler and Stephan 2007; Sbragia and Damro 1999).

So, by the early 1990s, the EU had strong incentives to try to export its environmental standards and an increasing capacity to do so. The EU deployed the strategies of 'exercising regulatory influence' and 'empowering international institutions' to manage globalization and to spread its environmental standards to other jurisdictions. Developments in the fields of GMO regulation, the fight against climate change and in the broader question of 'greening' the world trade regime illustrate these dynamics.

\section{GMOs}

In the 1990s, in response to mounting health, consumer safety and environmental concerns in Europe, the EU has established the most stringent regulatory regime for the authorization and labelling of GMOs in the world (Pollack and Shaffer 2005, Bernauer 2003). The EU adopted its first common legislation on GMOs in 1990 (Directive 90/220/EEC). Though public opinion on GMOs and initial policy reactions varied greatly among EU member states (Kurzer and Cooper 2007), states hostile to GMOs were able to dominate at the EU level and to force a de facto moratorium on new GM products in Europe from 1998. The EU introduced new common rules governing the experimental release, marketing, labelling and tracing of GMOs between 2001 and 2003 (Directive 2001/18/EC, Regulation 1830/2003/EC and Regulation 1829/2003/EC). The EU's approach to the regulation of GMOs was 
guided by 'the precautionary principle' -- the principle that policy-makers should act to restrict products that pose potential risks even where scientific uncertainty makes it impossible to assess the risk conclusively.

From the outset, the EU's regulatory regime for GMOs was confronted with 'globalization pressures' in the form of potential legal attacks before the WTO. The US, which took a far more lax approach to GMO regulation and was home to major producers and exporters of GMOs, viewed EU GMO regulations as an unjustified trade barrier (Vogel 2003, Young 2003, Bernauer 2003). When the EU tightened its restrictions on GMOs in 1998, the US threatened to take legal action before the WTO.

As popular backlash against 'Frankenstein foods' mounted in some member states, any possibility of resolving the dispute simply through opening the European market to GMOs became a political non-starter - even though this would have been the preferred solution of many in the European Commission (Young 2003). The EU responded by leading a drive to 'internationalize' its approach to GMO regulation through a protocol to the 1992 Convention on Biodiversity. The EU succeeded in spearheading the creation of the Cartagena Protocol on Biosafety in 2000 (Depledge 2000). The Cartagena Protocol adopted the EU's 'precautionary principle' as a potential justification for trade restrictions on genetically modified seeds and crops: in other words, by embracing the precautionary principle, Cartagena made it easier for countries to block imports of GMOs. Because of long-standing regulatory restrictions within the EU and consumer resistance to genetically modified foodstuffs, few European firms produced such genetically modified seeds or foodstuffs and few farmers grew them. As a result, these European commercial interests had little to lose from a Treaty like the Cartagena protocol that would restrict trade in GMOs. They did, however, stand to benefit if such restrictions raised costs or reduced demand for 
their GMO dependant American competitors By institutionalising its own standard at the international level, the EU also significantly enhanced the legitimacy of the 'precautionary principle' and increased the chance that EU rules might withstand scrutiny before the WTO. A domestic standard, like the precautionary principle, can hardly be treated as arbitrary or a completely unjustifiable trade barrier once it is enshrined in an international treaty signed by dozens of states.

Ultimately, the EU was at best partially successful. In 2003, the US, together with Canada and Argentina, brought a WTO action charging that the EU's de facto moratorium on GMOs between 1999 and 2003 violated world trade rules. In 2004, the EU lifted its moratorium, put in place a new system for the evaluation and authorisation of GMO products, and began to approve a handful of genetically modified foodstuffs (principally grains for animal feed). The WTO finally issued a ruling in February 2006, declaring that the EU's moratorium between 1999 and 2003 had been illegal. The EU accepted the ruling, but emphasized that the ruling did not invalidate the new system of GMO regulation it had put in place in 2004, which was based on scientific evaluation of GMOs, but still applied the precautionary principle (Alden and Grant 2006). The EU's strategy of shielding its own GMO policies by promoting the spread of the precautionary principle in the Cartagena Protocol had not prevented the US - which had refused to sign on to the Cartagena Protocol - from attacking it. However, it is likely that the existence of the Cartagena Protocol, endorsed by more than 130 countries, made the WTO panel less willing than it might otherwise have been to undertake a frontal assault on the new EU regulatory regime and the precautionary principle that underpins it.

\section{Climate change}


As in the case of GMOs, the interaction of domestic politics and regulatory competition also encouraged the EU to take on a leadership role in addressing climate change. As awareness of the threat posed by climate change increased in the late 1980s and early 1990s, domestic political pressure for action to curb greenhouse gas emissions mounted in Europe. National governments in the greenest member states acted first, with the Dutch, German and Danish governments making commitments to CO2 reductions in 1989 and 1990 (Porter and Brown 1991, p. 95). Quickly, the EU stepped in to develop a common approach, and the Council of Ministers announced that the EU as a whole, working through a 'burden-sharing' or 'bubble' approach, would seek to stabilize its CO2 emissions at 1990 levels by 2000. With this approach national commitments within the EU would be differentiated with some member states (principally the most economically developed ones) making the substantial reductions, and others (principally the less developed EU members) actually being permitted to increase emissions.

Turning to the international arena, the calculus for European policy-makers was clear: the bold, costly domestic actions on climate change that European publics demanded would put European industry at a competitive disadvantage unless an international agreement was reached that would force the EU's competitors to undertake costly measures as well. After proposing that the EU introduce a carbon tax in order to achieve the target for $\mathrm{CO} 2$ emissions reductions that it had set for itself in 1990, and the Commission pushed for industrialized nations to adopt similar energy taxes in the run-up to Rio. After other states refused to do so at the Rio Earth Summit, the Commission abandoned its carbon tax proposal in 1992.

The EU assumed an even more pronounced leadership role in the negotiations over the Kyoto Protocol between 1995 and 1997. In the negotiations leading to Kyoto, it 
was clear that the EU was willing to commit to costly measures - indeed the EU was committed to do so regardless of the outcome of Kyoto. It was also clear, from early in the negotiating process, that the costs of implementing Kyoto promised to be substantially less for the EU than for some other industrialized states - above all the US. One crucial factor was that 1990 was to be used as the base-line year against which mandatory reductions (of $8 \%$ for the EU and 7\% for the US) would measured. Using 1990 as a baseline allowed the EU to take advantage of reductions in emissions that were occurring in any case for idiosyncratic reasons - the switch from reliance on coal to natural gas in the UK in the first half of the 1990s and the shuttering of polluting industries in former East Germany after reunification which had led to massive reductions in CO2 emissions (Schreurs and Tiberghien 2007). As the EU was allowed to use a differentiated 'bubble' or burden sharing approach, the large 'exogenous' reductions occurring in Germany and the UK could be leveraged to eas the emissions reduction burden for other member states. Finally, the 1990 baseline had an other advantage for the EU in that the European economy - and associated CO2 emissions - had grown far more slowly in the 1990s than the US economy and US emissions. Therefore, by the time the Kyoto Protocol was signed in 1997, the US would have had to cut its projected emissions by 30-35\% to meet Kyoto’s 2012 target, where the EU would have only had to make cuts of $15-20 \% .^{3}$ Indeed, some observers have argued that the EU hoped to use climate change negotiations to pressure the US to raise its relatively low energy taxes and thus to create a more level competitive playing field (Yandle and Buck 2002:197). The point here is not to suggest that the EU asserted leadership on Kyoto simply in an effort to raise costs for competitors. The point, rather, is that because the EU was going to take substantial, highly costly action on greenhouse gas emissions in any case due to domestica political pressure, 
EU leaders clearly felt it imperative to press other states - particularly the advanced industrialized states - to join them in the fight against climate change.

Despite the EU's inability to secure US participation in the agreement, EU leadership on Kyoto should be viewed as a relatively successful case of managing globalization. Kyoto has 178 signatories, and the EU has played a pivotal role in persuading key hold-out states such as Russia to participate. Moreover, the EU has been able to use the framework provided by Kyoto and the UN Framework Convention on Climate Change (UNFCC) - with tools such as 'Clean Development Mechanism' (CDM) - projects to encourage developing countries to join the effort to combat climate change and to encourage them to adopt EU standards and technologies when doing so. For instance, within the UNFCC/Kyoto framework, the EU has worked closely with China, establishing the EU-China Partnership on Climate Change in 2005, which promotes the transfer of low carbon technologies and CDM projects involving European and Chinese partners.

Turning to the ongoing negotiations on a post-Kyoto framework for combating climate change, we can observe similar dynamics behind EU leadership. In 2007, when the European Commission announced new plans to combat climate change, Commission Preident Barroso acknowledged that the new rules would raise production costs and damage the competitiveness of EU industries. Therefore, the Commission proposed imposing a carbon tax on imports from countries that do not maintain similar restrictions on carbon emissions. French President Sarkozy expressed strong support for carbon tariffs, as did a number of members of the European Parliament and environmentalists. The fate of such proposals remains uncertain, but it is clear that many EU leaders are hoping to use the threat of 'carbon tariffs as a way to pressure reluctant developed states - such as the US - and 
developing states - such as China - to make binding commitments in a post-Kyoto framework. Having established its bona fides as an environmental leader in the earlier rounds of climate negotiations - and in negotiations on other environmental issues - it seems that the EU will now likely to rely more heavily on leveraging its market power to press other states to join it in making substantial commitments to reducing emissions.

\section{Greening World Trade}

The EU has attempted to manage the impact of globalization on environmental regulation through two principal strategies. First and foremost, the EU tried to 'globalize' the environmental standards it favors through MEAs, as illustrated above in the discussions of the Cartagena Protocol and the Kyoto Protocol. The EU's second strategy has been its broader effort to 'green' the international trade regime. The EU has pressed for changes to or interpretations of international trade rules (i.e. those of the WTO) that would allow them to accommodate EU environmental measures and commitments made by the EU under MEAs. Conflicts between free trade rules and EU environmental policy commitments have led the EU to a number of 'trade vs. environment' disputes before the WTO, including the Hormone Treated Beef and GMO disputes. The EU has defended itself vigorously in these cases, but the EU has also gone on the offense, attempting to manage globalization by greening global trade rules before it is forced to defend itself in a judicial setting.

The GATT's Article XX 'general exceptions' clause provides for exceptions to its free trade obligations that enable signatories to restrict trade on environmental grounds. During the Uruguay Round, the US and EU demanded the additional agreements that would clarify their right to maintain domestic environmental rules. 
The Agreements on Sanitary and Phytosanitary Measures (SPS) and Technical Barriers to Trade (TBT) concluded during the Uruguay round elaborated these conditions (Steinberg 1997).

Beginning in the mid-1990s, the EU raised particular concerns regarding the relationship between trade obligations contained in MEAs and general free trade rules of the GATT/WTO. The problem that they highlighted was that MEAs contain various trade measures including, trade bans, export and import licensing procedures and notification, packaging and labelling requirements. For instance, the Convention on Trade in Endangered Species (CITES) restricts trade in endangered animal species, and the Montreal Protocol bans the import of CFCs from non-parties. The EU was concerned with how the WTO would resolve disputes between free trade requirements and trade restrictions called for in international environmental treaties.

In the Doha Round trade negotiations, the EU has taken a lead role in pushing for reforms to the GATT that would give trade measures contained in MEAs supremacy over WTO requirements in cases of conflict. The EU began promoting this position prior to Doha, when, in 1996, it pressed the WTO's Committee on Trade and the Environment to add a reference to MEA trade provisions and other "measures necessary to protect the environment” to GATT’s Article XX exceptions (Stoler 2004; See also Steinberg 1997). In recent negotiations, the EU has retreated somewhat, but still calls for MEAs and the WTO to be treated as equal bodies of international law and for the WTO to defer to MEAs on environmentally related trade restrictions.

Taking a step back, we can see how the EU's drive to make trade restrictions required by MEA's effectively 'WTO-proof', meshes with its consistent leadership on MEAs. The EU recognizes that standing in isolation, many of its environmental policies - particularly those based on the precautionary principle - may not withstand 
scrutiny with the WTO. However, where the EU can internationalise its standards by convincing other countries to sign on to them in an MEA, then these standards gain international legitimacy and may withstand legal challenges at the WTO.

\section{Conclusions}

To be sure, many factors have contributed to the rise of the EU as the undisputed leader in global environmental governance. A series of legal and political reforms and the EU's broad commitment to developing common foreign economic policy increased the EU's capacity to act in a cohesive fashion in the environmental arena. Global environmental problems, by their very nature, call for multilateral solutions. Thus, the environment was a natural focus for the many EU leaders committed to the EU developing an identity as a 'civilian' or 'normative' power on the world stage. The US retreat from leadership made this more attractive, in that the EU could contrast its virtuous, environmental leadership with the US' rogue behaviour. While these factors certainly played a role, the roots of the EU's commitment to global environmental leadership can be found at the intersection of domestic politics and international political economy. In the 1990s, the dramatic increase in power of environmental interests across Europe, and the dynamics of EU policy-making which encouraged harmonization at high levels of environmental protection led the EU to adopt the strictest, most ambitious environmental legislation in the world. Given that strict standards were being put in place across Europe, it was in the interests of European industry and European governments to see similar standards spread to other jurisdictions.

The role of the EU in championing MEAs is well illustrated above in the discussions of the Cartagena Protocol and the Kyoto Protocol. The most striking 
aspect of the EU's position on MEAs is the sheer consistency with which it has supported them in recent years. The EU has emerged as a leading supporter of every major international environmental treaty since 1989. By consistently positioning itself as an environmental leader, the EU has spread a number of its environmental standards to other jurisdictions and has built up a reservoir of credibility in this policy domain, which it may draw on in defending new measures against accusations that they constitute veiled protectionism. The EU has also worked to 'green' the world trade regime, elevating the status of MEAs vis-à-vis WTO rules. In all of this, the EU has not idly waited for the pressures of globalization to undermine its commitment to environmental policy. Instead, the EU has taken a leadership role and gone on the offensive to manage globalization or - to paraphrase Woodrow Wilson in a very different context - to make the world safe for environmental policy.

These dynamics clearly extend beyond the specific cases discussed above and can be observed in other areas of environmental, consumer protection and economic regulation. For instance, as the EU developed its ambitious new regulatory regime for chemicals (REACH), it simultaneously sought to influence international debates concerning chemicals regulation (Fisher 2008, Pesendorfer 2006). In attempting to spread its strict chemical safety standards, the EU is both leveraging its market power by requiring all foreign manufacturers exporting to the European market to comply with REACH and is supporting strengthening international initiatives on chemicals regulation - above all the 2001 Stockholm Convention on Persistent Organic Pollutants. Moving beyond the environmental field, in areas including data privacy regulation, securities regulation, telecoms regulation, accounting standards and pharmaceutical standards, we can observe similar processes at work with the EU harnessing its market power and multilateral agreements to 'globalize’ its standards 
(Bach and Newman 2007; Glimstedt 2001; Mattli and Büthe 2003; Shaffer 2002; Mitchener 2002).

R. Daniel Kelemen is Associate Professor of Political Science at Rutgers University.

Address for Correspondence:

Department of Political Science, Rutgers University, New Brunswick, NJ, 08901, USA. Email: dkelemen@polisci.rutgers.edu

Acknowledegements: The author thanks Sophie Meunier, Wade Jacoby, Mark Pollack, David Vogel, Joseph Jupille, Paulette Kurzer, Nicolas Jabko and other participants in the 'Europe and the Management of Globalization' Workshop at Princeton University for comments and suggestions and thanks the Institute for Advanced Study for research support. 


\section{References}

Alden, E. and J. Grant. (2006). WTO rules against Europe in GM food case. Financial Times, February 7.

Bach, D. and A. Newman. 2007. The European regulatory state and global public policy. European Journal of Public Policy 16(4).

Bernauer, T. (2003). Genes, Trade and Regulation. Princeton: Princeton University Press.

Commission of the European Communities White Paper on the Strategy for a Future Chemicals Policy COM (2001) 88 final

Depledge, J. (2000). The Cartagena Protocol on Biosafety. Environmental Politics 9(2):156-162.

DeSombre, E. (2000). Domestic Sources of International Environmental Policy. Cambridge: MIT Press.

Duchêne, F. (1972). Europe in World Peace. In R. Mayne (ed.) Europe Tomorrow. London: Fontana/Collins.

Environmental News Service (ENS). (2004). Europe Gets New Leadership, Ratifies POPS Treaty. ENS-Newswire, November 19. Available at: http://www.ensnewswire.com/ens/nov2004/2004-11-19-04.asp

Farrell, M. (2007). From EU Model to External Policy? In Sophie Meunier and Kathleen McNamara, Eds. Making History, The State of the European Union, Vol. 8. Oxford: Oxford University Press.

Fisher, E. (2008). The 'Perfect Storm' of REACH. Journal of Risk Research 11: 541563.

Frank, D. (1999). The Social Bases of Environmental Treaty Ratification, 1900-1990. Sociological Inquiry 69(4):523-550. 
Franzen, A. (2003). Environmental Attitudes in International Comparison. Social Science Quarterly, 84(2):297-308.

Glimstedt, H. (2001). Competitive Dynamics of Technological Standardization: The case of third generation cellular communications. Industry and Innovation 8(1): 49-78.

Hettne, B., and F. Söderbaum. (2005). Civilian Power or Soft Imperialism? European Foreign Affairs Review 10: 535-552.

Hofrichter, J. and K. Reif. (1990). Evolution of Environmental Attitudes in the European Community. Scandinavian Political Studies 13(2): 119-146.

Jacoby, W. and S. Meunier. 2008. Europe and the Management of Globalization. This issue.

Jupille, J. and J. Caporaso. 1998. States, Agency, and Rules: The European Union in Global Environmental Politics. In C. Rhodes (ed.) The European Union in the World Community. Boulder: Lynne Rienner.

Kelemen, R. D. (2004). The Rules of Federalism. Cambridge, MA: Harvard University Press.

Kurzer, P. and A. Cooper. (2007). What's for dinner? European farming and food traditions confront American biotechnology. Comparative Political Studies 40: 1035-1058

Mair, P. (2001). The Green Challenge and Political Competition. German Politics 10 (2):99-116.

Manners, I. (2002). Normative Power Europe: A Contradiction in Terms? Journal of Common Market Studies. 40(2):235-58.

Mattli, W. and T. Büthe. (2003). Setting International Standards. World Politics 56(1):1-42. 
Mitchener, B. (2002). Rules, Regulations of the Global Economy are Increasingly Being Set in Brussels. The Wall Street Journal, April 23.

Pesendorfer, D.( 2006). EU environmental policy under pressure. Environmental Politics 15, 95-114.

Pollack, M. and G. Shaffer. (2005). Biotechnology Policy. In H. Wallace, W. Wallace and M. Pollack. Policy-Making in the European Union, $5^{\text {th }}$ Edition. Oxford: Oxford University Press.

Porter, G. and J.W. Brown. (1991). Global Environmental Politics. Boulder, CO: Westview Press.

Prodi, R. (2000). '2000-2005: Shaping the New Europe.” Speech to the European Parliament, Strasbourg, 15 February, Speech/00/41.

Raustiala, K. (1997). Domestic Institutions and International Regulatory Cooperation. World Politics 49(4): 482-509.

Recchia, S. (2002). International Environmental Treaty Engagement in 19 Democracies. Policy Studies Journal 30(4): 470-494.

Roberts, J. T, B. Parks and A. Vásquez. (2004). Who Ratifies Environmental Treaties and Why? Global Environmental Politics 4(3):22-64.

Sbragia, A. (2000). Environmental Policy. In H. Wallace and W. Wallace, Policymaking in the European Union, $4^{\text {th }}$ ed. Oxford: Oxford University Press.

Sbragia, A. and C. Damro. (1999). The Changing role of the European Union in international environmental politics. Environment and Planning C: Government and Policy, 17(1): 53-68.

Sbragia, A. and P. Hildebrand. (2000). The European Union and Compliance. In E.B. Weiss and H. Jacobson eds. Engaging Countries. Cambridge: MIT Press, pp. 215252. 
Scheipers, S. and D. Sicurelli. (2007). Normative Power Europe: A credible utopia? Journal of Common Market Studies, 45(2):435-457.

Schreurs, M.. (2005). Global Environment Threats in a Divided Northern Community. International Environmental Agreements 5:349-376.

Schreurs, M. and Y. Tiberghien. (2007). Multi-level reinforcement: Explaining EU Leadership in Climate Change Mitigation. Global Environmental Politics 7(4): 19-46.

Scruggs, L. (2003). Sustaining Abundance. New York: Cambridge University Press. Shaffer, G. (2002). Reconciling Trade and Regulatory Goals. Columbia Journal of European Law 9:29.

Steinberg, R. (1997). Trade-Environment Negotiations in the EU, NAFTA and WTO. The American Journal of International Law. 91(2): 231-267.

Stoler, A. (2004). The Doha Round Negotiations on the MEA-WTO Interface. Paper presented at the International Bar Association Conference, 26 October, Auckland, NZ.

Vogel, D. (1995). Trading Up. Cambridge, MA: Harvard University Press.

----. 2003. The Hare and the Tortoise Revisited. British Journal of Political Science 33:557-580.

Vogel, D. and R.D. Kelemen. (Forthcoming). Trading Places: the US and EU in international environmental politics. Comparative Political Studies, forthcoming.

Vogler, J. and H. Stephan. (2007). The European Union in global environmental governance.International Environmental Agreements, 7: 389-413.

Young, A. (2003). Political transfer and “Trading UP”? World Politics 55:457-84.

Yandle, B. and S. Buck. (2002). Bootleggers, Baptists, and the Global Warming Battle. Harvard Environmental Law Review 26:177-229. 
Zielonka, J. (1998). Explaining Euro-Paralysis. Basingstoke: Macmillan.

\footnotetext{
${ }^{1}$ By “domestic" I mean political forces within Europe, including those at the national level and the EU level.

${ }^{2}$ The EEC was first allowed to sign on to international environmental agreements in 1979 in the context of negotiations on the Long Range Transboundary Air Pollution Convention (LRTAP). See Vogler and Stephan 2007,p. 396.

3 "The Collapse of Kyoto", Oil and Gas Journal 49, Dec. 4, 2000, p.25.
} 